\title{
Edu-PHOTSIC (Education Program for Test of High Order Thinking Skill in Chemistry): Upaya meningkatkan kemampuan peserta didik SMAN 2 Siak Hulu dalam menghadapi ujian nasional
}

\author{
Siti Imroatus Sa'adah
}

Universitas Riau

\section{3imro@gmail.com}

\begin{abstract}
Abstrak. Ujian nasional sebagai salah satu evaluasi dalam tolak ukur standar nasional untuk mencapai kualitas peserta didik, sudah seharusnya komponen soal dengan kemampuan berfikir tingkat tinggi (HOTS). Salah satunya ujian nasional pada mata pelajaran kimia. Namun Kebermaknaan pelajaran kimia yang terkait dengan kehidupan sehari-hari masih belum diintegrasikan dalam proses belajar mengajar secara maksimal karena guru mengejar target mengajar. Hal ini dialami oleh SMAN 2 Siak Hulu. Berdasarkan data Puspendik Kemendikbud (2017) yang menunjukkan nilai UN SMAN 2 Siak Hulu dari tahun 2015 hingga 2017 pada mata pelajaran kimia mengalami penurunan secara berturut turut diperoleh 78,13 (2015), 63,86 (2016) dan 48,33 (2017). Hal ini menunjukkan pengenalan soal HOTS dalam pembelajaran kimia masih relatif minim, oleh karena itu diperlukan kegiatan pengabdian kepada masyarakat (PKM), agar guru dan peserta didik memahami soal HOTS dengan mengikuti program Edu-PHOTSIC. Kegiatan program EduPHOTSIC dilakukan dalam tiga tahap yang terdiri dari Tahap persiapan, Tahap pelaksanaan dan tahap pelaporan. Hasil kegiatan ini menunjukkan adanya peningkatan pemahaman mengenai penggunaan dan pengerjaan soal HOTS oleh guru dan peserta didik
\end{abstract}

Kata kunci: Edu-PHOTSIC; high order thinking skills; SMAN 2 Siak Hulu; ujian nasional

\begin{abstract}
National examination, as an evaluation of national standard benchmarks to achieve good quality students, should have had questions component with high order thinking skills (HOTS). HOTS questions should be applied in national-level subject such as chemistry. The significance of a lesson related to the daily life activities was still not yet integrated in the learning process comprehensively due to several targets that needed to be completed by the teachers. This kind of problems was experienced by students in SMAN Siak Hulu. According to Puspendik Kemendikbud (2017) that showed the results of National Exam of SMAN Siak Hulu from 2015 up to 2017, it proved that the average scores of Chemistry subject decreased year by year in a row; 78.13 (2015), 63.86 (2016), and 48.33 (2017). This issue signified that HOTS orientation in Chemistry class was still relatively low. Therefore, Community Service (PKM) activities are needed, So that teachers and students could comprehend the HOTS question by joining Edu-PHOTSIC program.Edu-PHOTSIC program was conducted in three phases; preparation phase, implementation phase, and report phase. The results of this program showed that there was an improvement of understanding about the use and implementation of HOTS question by teachers and students.
\end{abstract}

Keywords: Edu-PHOTSIC; high order thinking skills; SMAN 2 Siak Hulu; national exam

To cite this article: Sa'adah, S. I. 2019. Edu-PHOTSIC (Education Program for Test of High Order Thinking Skill in Chemistry): Upaya meningkatkan kemampuan peserta didik SMAN 2 Siak Hulu dalam menghadapi ujian nasional. Unri Conference Series: Community Engagement 1: 150-157. https://doi.org/10.31258/unricsce.1.150-157

(C) 2019 Author

Peer-review under responsibility of the organizing committee of Seminar Nasional Pemberdayaan Masyarakat 2019 


\section{PENDAHULUAN}

SMAN 2 Siak Hulu terletak di Kecamatan Siak Hulu, Kabupaten Kampar. Sekolah SMAN 2 Siak Hulu memiliki sarana dan prasarana yang memadai. Namun dengan kualitas yang dianggap unggul, bukan berarti peserta didik di SMAN 2 Siak Hulu memiliki kemampuan berpikir tingkat tinggi dalam memecahkan masalah khususnya materi kimia. Hal ini didasarkan pada hasil nilai UN yang didata oleh puspendik kemendikbud khususnya mata pelajaran kimia dari tahun 2015 hingga 2017 mengalami penurunan dari 78,13 hingga 48,33.

Menyongsong visi pendidikan nasional tahun 2025 dibutuhkan generasi penerus bangsa yang cerdas dan terampil dengan menekankan pentingnya peserta didik berpikir tingkat tinggi. Namun pada kenyataannya, peserta didik masih belum terbiasa mengerjakan soal HOTS dikarenakan peserta didik belum terbiasa mengerjakan soal HOTS kimia dalam kegiatan evaluasi. Hal ini menjadi perhatian Tim Edu-PHOTSIC untuk memilih SMAN 2 Siak Hulu sebagai sasaran lokasi kegiatan pengabdian. Sehingga dengan pengenalan program Edu-PHOTSIC diharapkan sebagai upaya peningkatan kemampuan peserta didik SMAN 2 Siak Hulu dalam menghadapi ujian nasional, salah satunya UNBK karena selain memberikan edukasi soal HOTS juga membuat peserta didik terampil dalam mengerjakan UN dalam sistem IT (Information Technology).

\section{MASALAH}

Bagaimana bentuk pelatihan Edu-PHOTSIC pada guru dan peserta didik SMAN 2 Siak Hulu mengenai materi kimia sebagai upaya meningkatkan kemampuan dalam menghadapi UN?

\section{METODE}

Metode yang digunakan dalam melaksanakan pengabdian kepada masyarakat disusun secara sistematis dalam flow map yang dapat dilihat pada Gambar 1.



Gambar 1. Flowmap Kegiatan

Berdasarkan flowmap kegiatan dapat didefiniskan sebagai berikut:

1. Tahap persiapan meliputi penetapan daerah sasaran lokasi kemudian observasi lapangan, pembuatan surat pernyataan kerjasama dengan mitra dan rancangan kegiatan sosialisasi. Kemudian dilanjutkan dengan sosialisasi Edu-PHOTSIC terkait program edukas soal HOTS untuk melihat pemahaman soal HOTS 
dalam jangka pendek pada guru dan peserta didik SMAN 2 Siak Hulu serta tahap pre-test guru dan peserta didik untuk melihat perkembangan tingkat pengetahuan soal HOTS.

2. Tahap pelaksanaan

a. Edu-PHOTSIC Show; mengenai penyampaian cara pembuatan soal HOTS khususnya pada materi kimia kelas X, bagaimana berpikir kritis peserta didik dan proses tanya jawab tentang HOTS yang belum diketahui peserta didik dan guru tersebut dan juga disajikan buku saku Edu-PHOTSIC sehingga membuat peserta didik lebih memahami kegitan ini.

b. Demonstrasi Edu-PHOTSIC; melaksanakan kegiatan bedah buku dan bedah soal terkait soal HOTS untuk memberikan pemahaman yang lebih jelas kepada peserta didik SMAN 2 Siak Hulu yang mengikuti Edu-PHOTSIC.

c. Latihan; melaksanakan kegiatan latihan soal HOTS untuk melihat kemampuan peserta didik dalam persiapan menghadapi UN baik berbasis cetak dan IT, sehingga selain memberikan edukasi terkait soal HOTS juga melatih peserta didik agar terampil mengerjakan soal HOTS dengan sistem IT demi menyongsong abad 21. Kemudian diberikan post-test dalam bentuk kuisioner yang dibagikan kepada peserta didik hal ini bertujuan untuk mengetahui tingkat keberhasilan setelah mengikuti program Edu-PHOTSIC.

d. Evaluasi, review dan follow up guru.

i. Evaluasi dan review berperan penting untuk mengetahui apakah peserta didik yang telah mengikuti program-program Edu-PHOTSIC dapat menambah tingkat pemahaman soal HOTS sesuai dengan indikator keberhasilan yang diharapkan oleh tim Edu-PHOTSIC. Evaluasi ini dapat dilihat perbandingan dari hasil pre-test dan hasil post-test.

ii. Follow up bertujuan untuk melihat kegiatan guru terhadap Edu-PHOTSIC secara berkelanjutan sebagai upaya meningkatkan kemampuan peserta didik dalam mengahadapi ujian nasional.

3. Tahap Pelaporan meliputi analisis hasil pengabdian dari data kuisioner awal dan akhir serta latihan HOTS yang dikerjakan peserta didik.

\section{Teknik Penyuluhan}

Penyuluhan yaitu pelatihan program Edu-PHOTSIC terhadap guru dan peserta didik SMAN 2 Siak Hulu tentang penggunaan dan pengerjaan soal HOTS. Tahap pelaksanaan penyuluhan program Edu-PHOTSIC, pada tahap pre-test memberikan edukasi mengenai soal HOTS kepada guru dan peserta didik diawali dengan pertanyaan singkat untuk mengetahui sejauh mana pemahaman guru dan peserta didik SMAN 2 Siak Hulu tentang soal HOTS berbasis cetak dan IT. Kemudian pengenalan tentang kisi-kisi soal HOTS, teknik penulisan soal HOTS, penggunaan aplikasi wondershare quiz creator dalam mengerjakan soal HOTS berbasis IT khususnya pada materi kimia kelas $\mathrm{X}$ dalam kegiatan Edu-PHOTSIC show. Selanjutnya, memberikan pemahaman yang lebih jelas mengenai soal HOTS dengan melakukan demonstrasi Edu-PHOTSIC buku SPM Kimia yang berisikan soal-soal Ujian Nasional untuk SMA/MA dan buku paket soal HOTS. Siti Imroatus et al. (2019) menyatakan bahwa soal dalam paket yang akan diajarkan ke peserta didik sebelumnya sudah diikutsertakan dalam program PKM-P, dimana pada program PKM-P soal-soal HOTS telah divalidasi oleh validator ahli materi sehingga soal HOTS yang dikembangkan sudah dinyatakan valid dan reliable. Kemudian, mengadakan latihan dengan dua versi yaitu soal HOTS berbasis cetak dan IT dengan menggunakan aplikasi wondershare quiz creator Tahap akhir berupa tahap post-test, memberikan pertanyaan tentang kegiatan yang telah disampaikan untuk mengetahui bagi peserta didik sejauh mana perkembangan dan kesiapan peserta didik dalam menghadapi ujian nasional setelah mengikuti program Edu-PHOTSIC. Dilanjutkan evaluasi, review untuk mengetahui apakah peserta didik yang telah mengikuti program-program Edu-PHOTSIC dapat menambah tingkat pemahaman soal HOTS sesuai dengan indikator keberhasilan yang diharapkan oleh tim Edu-PHOTSIC dan follow up untuk melihat kegiatan guru terhadap Edu-PHOTSIC secara berkelanjutan sebagai upaya meningkatkan kemampuan peserta didik SMAN 2 Siak Hulu dalam mengahadapi ujian nasional.

\section{Pelatihan}

Pelatihan merupakan proses implementasi dari materi yang telah diberikan dalam kegiatan penyuluhan. Pelatihan berfungsi untuk meningkatkan pengetahuan guru dan peserta didik dalam pemahaman mengenai soal HOTS. Selain itu, pelatihan juga berfungsi untuk meningkatkan penggunaan soal HOTS oleh guru dan pengerjaan soal HOTS oleh peserta didik. 


\section{PEMBAHASAN}

Hasil yang telah dicapai dari kegiatan pengabdian Edu-PHOTSIC mengacu pada indikator keberhasilan selama pelaksanaan seluruh kegiatan pengabdian yang dapat dilihat dari jumlah mitra yang telah dihasilkan. Berikut ini merupakan hasil yang dicapai selama pelaksanaan kegiatan pengabdian diantaranya sebagai berikut:

1. Mengenalkan Edu-PHOTSIC kepada peserta didik dan Penggunaan soal HOTS oleh guru dalam pembelajaran kimia di SMAN 2 Siak Hulu yang telah dilaksanakan pada tanggal 26 April - 8 Mei 2019. Peserta pada program Edu-PHOTSIC ini adalah peserta didik kelas X dan XI serta guru kimia. Pengabdian Edu-PHOTSIC sekaligus sebagai keberlanjutan program Edu-PHOTSIC.

2. Banner dan buku saku yang berisikan Edu-PHOTSIC mengenai latar belakang, tahapan kegiatan pengabdian mengenai penggunaan dan pengerjaan soal HOTS oleh guru dan peserta didik. Buku saku mengenai panduan pembuatan soal HOTS dan penggunaan aplikasi wondershare quiz creator sebagai pedoman dalam pengenalan dan pemahaman terkait soal HOTS.

3. Publikasi Edu-PHOTSIC dalam media online dan cetak ; dalam media online yaitu datariau.com, riauterkini.com (RTC), riaubarometer.com, riaumandiri.co, bualbual.com, dan lamanriau.com serta publikasi Edu-PHOTSIC dalam media cetak. Publikasi Edu-PHOTSIC ini mengenai kegiatan pengabdian yang telah dilakukan sebagai informasi inspiratif mengenai pengenalan dan pemahaman soal HOTS kepada guru dan peserta didik.

4. Buku paket soal HOTS, sticker dan brosur; Buku paket soal HOTS berisikan kumpulan paket soal HOTS materi kimia kelas $\mathrm{X}$ yang dikemas dalam bentuk cetak sekaligus dikonversi kedalam sistem IT dengan menggunakan aplikasi wondershare quiz creator yang dikemas dalam CD; Sticker mengenai pemahaman tentang HOTS dapat berupa motivasi inspiratif kepada peserta didik dalam memahami soal HOTS. Brosur mengenai pengenalan dan cara penulisan soal HOTS sekaligus penggunaan aplikasi wondershare quiz creator.

5. Artikel ilmiah Edu-PHOTSIC upaya meningkatkan kemampuan peserta didik SMAN 2 Siak Hulu dalam menghadapi ujian nasional yang akan diterbitkan pada jurnal pengabdian.

6. Seminar Edu-PHOTSIC upaya meningkatkan kemampuan peserta didik SMAN 2 Siak Hulu dalam menghadapi ujian nasional yang akan diseminarkan dalam seminar pengabdian.

7. Penyuluhan Edu-PHOTSIC dengan persentase terhadap target kegiatan diantaranya:

\section{Tahap Persiapan Edu-PHOTSIC}

Persiapan yang dilakukan meliputi penetapan daerah sasaran lokasi yang kemudian dilanjutkan dengan observasi lapangan. Penetapan daerah lokasi sasaran yaitu di SMAN 2 Siak Hulu, hal ini didasarkan dengan tingkat pemahaman soal HOTS dalam mata pelajaran kimia yang ada di SMAN 2 Siak Hulu masih dikategorikan rendah dan edukasi mengenai HOTS belum optimal. Tahap berikutnya melakukan rancangan kegiatan sosialisasi Edu-PHOTSIC untuk pengenalan soal HOTS baik berbasis cetak dan IT. Soal HOTS berbasis IT merupakan soal HOTS cetak yang dikonversi kedalam sistem IT dengan menggunakan aplikasi Wondershare Quiz Creator. Aplikasi Wondershare Quiz Creator adalah sebuah aplikasi yang digunakan dalam pembuatan ujian online atau yang dikenal dengan electronic test dengan cara meng-upload file dari aplikasi sebuah website (Dafitri, 2017).

Kegiatan sosialisasi Edu-PHOTSIC telah dilaksanakan pada hari Jum'at, 26 April 2019 di SMAN 2 Siak Hulu. Pada tahap kegiatan sosialisasi Edu-PHOTSIC ini dilakukan untuk melihat pemahaman soal HOTS dalam jangka pendek dengan memberikan kuisioner (pre-test) kepada peserta didik dan guru kimia SMAN 2 Siak Hulu. Tahap pre-test dilakukan untuk memberikan edukasi mengenai soal HOTS kepada guru dan peserta didik SMAN 2 Siak Hulu diawali dengan pertanyaan singkat untuk mengetahui sejauh mana pemahaman guru dan peserta didik SMAN 2 Siak Hulu tentang soal HOTS berbasis cetak dan IT. Kegiatan sosialisasi EduPHOTSIC dapat dilihat pada Gambar 2.

Berdasarkan data sebaran kuisioner pada pre-test dari dua guru kimia di SMAN 2 Siak Hulu menunjukkan sebanyak $40 \%$ guru kimia yang mengetahui tentang soal HOTS. Hasil kuisioner pre-test guru menurut Sugiyono (2015) persentase skor tersebut berada pada range persentase skor 40\%-59\% termasuk dalam kategori sedang. Secara keseluruhan hal ini memperlihatkan masih sedikitnya guru yang memahami penggunaan soal HOTS baik berbasis cetak dan IT, berdasarkan saran yang diberikan guru pada kuisioner pretest, guru sangat membutuhkan pelatihan mengenai soal HOTS yang nantinya dapat membantu guru membuat soal yang mengacu ke level HOTS sesuai dengan tuntutan kurikulum 2013 secara berkelanjutan. 


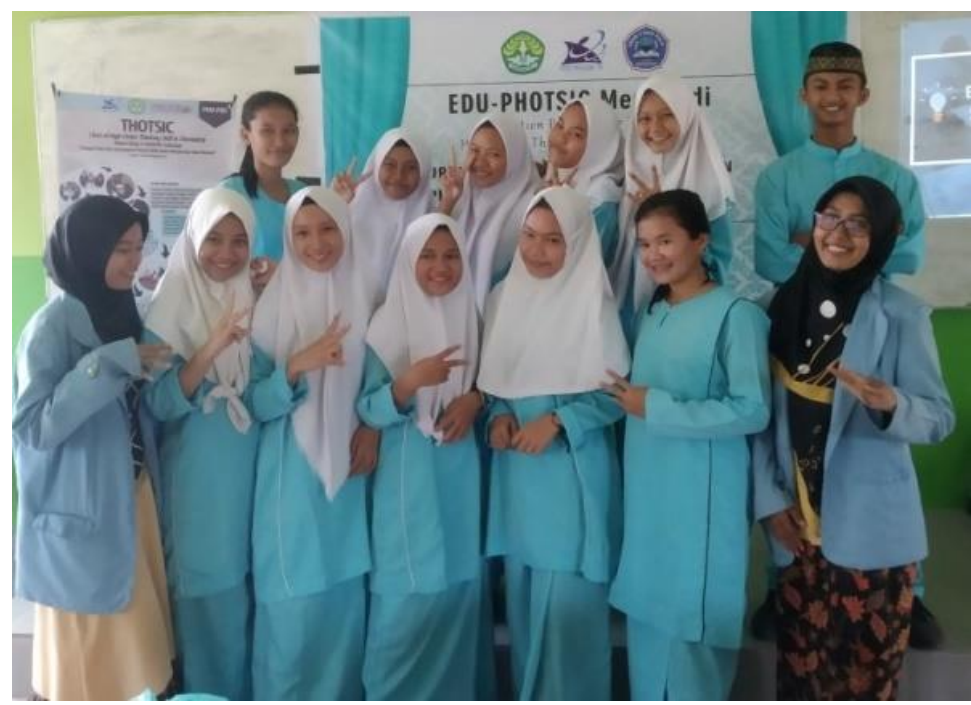

Gambar 2. Sosialisasi Edu-PHOTSIC

Kemudian berdasarkan data sebaran kuisioner pada pre-test dari delapan peserta didik di SMAN 2 Siak Hulu menunjukkan sebanyak $36 \%$ peserta didik yang mengetahui tentang pengerjaan soal HOTS. Hasil kuisioner pre-test peserta didik menurut Sugiyono (2015) persentase skor tersebut berada pada range persentase skor 20\%-39\% termasuk dalam kategori rendah. Secara keseluruhan hal ini memperlihatkan masih sedikitnya peserta didik yang memahami tentang mengerjakan soal HOTS cetak maupun keterampilan dalam mengerjakan soal HOTS dalam sistem IT, berdasarkan saran yang diberikan peserta didik pada kuisioner pretest, peserta didik sangat membutuhkan pelatihan bagaimana cara pengerjaan soal HOTS. Diagram lingkaran hasil kuisioner pre-test guru dan peserta didik terhadap penggunaan soal HOTS dalam program Edu-PHOTSIC dapat dilihat pada Gambar 3.

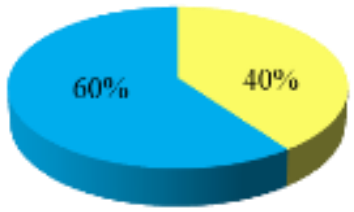

(a) Guru

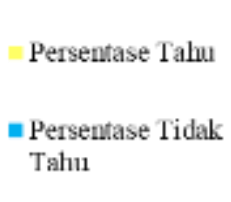

Gambar 3. Hasil kuisioner pre-test Guru dan Peserta Didik

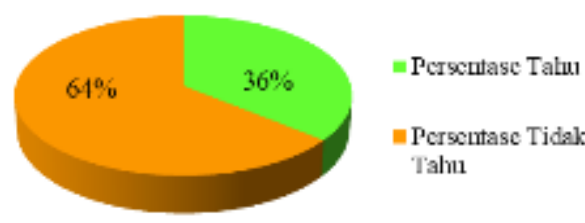

(b) Peserta Didik

\section{Tahap Pelaksanaan Edu-PHOTSIC}

\section{Edu-PHOTSIC Show}

Edu-PHOTSIC Show telah dilaksanakan pada hari Jum'at, 26 April 2019 di SMAN 2 Siak Hulu. EduPHOTSIC show dilakukan terkait pengenalan tentang kisi-kisi soal HOTS, teknik penulisan soal HOTS, penggunaan aplikasi wondershare quiz creator dalam mengerjakan soal HOTS berbasis IT khususnya pada materi kimia kelas X. Guru kimia dan peserta didik dalam program Edu-PHOTSIC diberikan buku saku mengenai panduan pembuatan soal HOTS dan penggunaan aplikasi wondershare quiz creator sebagai pedoman dalam pengenalan dan pemahaman terkait soal HOTS. Gambar buku saku panduan pembuatan soal HOTS dan penggunaan aplikasi wondershare quiz creator dapat dilihat pada Gambar 4.

Demonstrasi Edu-PHOTSIC

Demonstrasi Edu-PHOTSIC dilaksanakan pada hari Jum'at, 3 Mei 2019 di SMAN 2 Siak Hulu. Demonstrasi Edu-PHOTSIC dilakukan dengan bedah buku dan soal terkait soal HOTS untuk memberikan pemahaman yang lebih jelas mengenai soal HOTS. Guru dan peserta didik diberikan buku SPM Kimia yang berisikan soal-soal Ujian Nasional untuk SMA/MA dan buku paket soal HOTS. Siti Imroatus Sa'adah et al (2019) menyatakan bahwa soal dalam paket yang akan diajarkan ke peserta didik sebelumnya sudah diikutsertakan dalam program PKM-P, dimana pada program PKM-P soal-soal HOTS telah divalidasi oleh validator ahli materi sehingga 
soal HOTS yang dikembangkan sudah dinyatakan valid dan reliable. Gambar buku dalam demonstrasi EduPHOTSIC dapat dilihat pada Gambar 5.

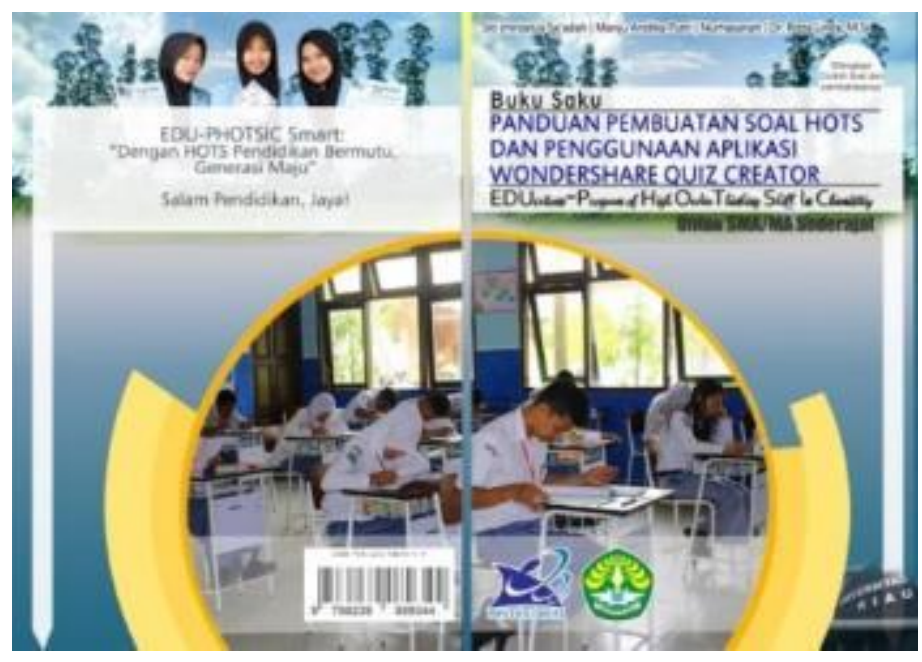

Gambar 4. Buku Saku Edu-PHOTSIC

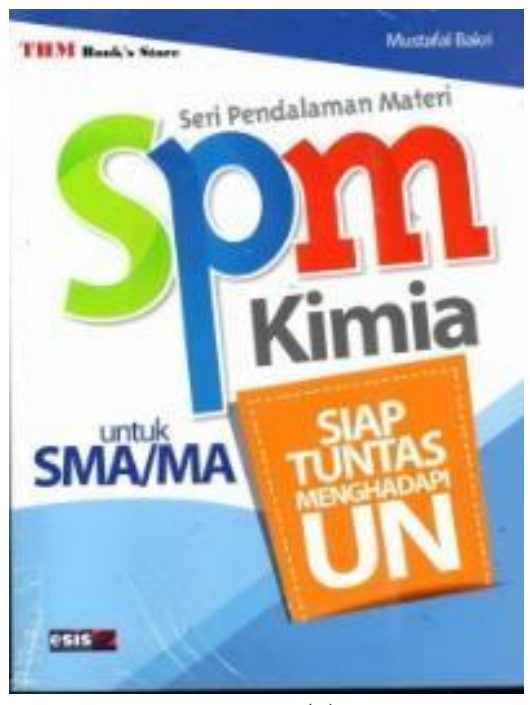

(a)



(b)

Gambar 5. (a) Bedah buku SPM Kimia dan (b) Bedah Buku Soal HOTS

\section{Latihan Soal HOTS dan Hasil Kuisioner Post-Test}

Latihan dilakukan dengan dua versi yaitu soal HOTS berbasis cetak dan IT dengan menggunakan aplikasi wondershare quiz creator. Latihan soal HOTS berbasis cetak telah dilaksanakan pada hari Jum'at, 03 Mei 2019 di SMAN 2 Siak Hulu. Latihan soal ini terdiri dari lima buah paket soal dengan 20 butir soal HOTS dalam satu paket. Masing-masing peserta didik mendapatkan satu paket soal yang berbeda dengan alokasi waktu selama 90 menit. Selama latihan soal HOTS berlangsung terdapat beberapa peserta didik yang excited dan ada juga yang mengalami kesulitan dalam mengerjakan soal HOTS terutama pada peserta didik kelas XI karena sebagian besar sudah mulai lupa mengenai materi kelas X.

Latihan soal HOTS berbasis IT telah dilaksanakan pada hari Rabu, 08 Mei 2019 di SMAN 2 Siak Hulu. Peserta didik diberikan softfile paket soal HOTS kemudian masing-masing peserta didik mengerjakan satu paket soal yang berbeda dengan alokasi waktu pada aplikasi wondershare quiz creator selama 90 menit dengan menggunakan laptop. Selama latihan soal HOTS berlangsung terdapat beberapa peserta didik yang excited terhadap soal HOTS berbasis IT namun beberapa peserta didik juga belum terampil menggunakan aplikasi IT.

Berdasarkan data sebaran kuisioner pada post-test dari dua guru kimia di SMAN 2 Siak Hulu menunjukkan sebanyak $86 \%$ guru telah mengetahui dalam pembuatan soal HOTS setelah mengikuti program EduPHOTSIC. Hasil kuisioner post-test guru menurut Sugiyono (2015) persentase skor tersebut berada pada range persentase skor 80\%-100\% termasuk dalam kategori sangat kuat. Pada kuisioner ini juga didapat hasil bahwa 
guru mempunyai peran penting dalam melatih mengajarkan soal HOTS kepada peserta didik sesuai dengan tuntutan kurikulum 2013 secara berkelanjutan.

Kemudian berdasarkan data sebaran kuisioner pada post-test dari delapan peserta didik di SMAN 2 Siak Hulu kelas X dan XI menunjukkan sebanyak 85\% peserta didik telah memahami pengerjaan soal HOTS. Hasil kuisioner post-test peserta didik menurut Sugiyono (2015) persentase skor tersebut berada pada range persentase skor $80 \%-100 \%$ termasuk dalam kategori sangat tinggi. Diagram lingkaran hasil kuisioner post-test guru dan peserta didik terhadap penggunaan soal HOTS dalam program Edu-PHOTSIC dapat dilihat pada Gambar 6.

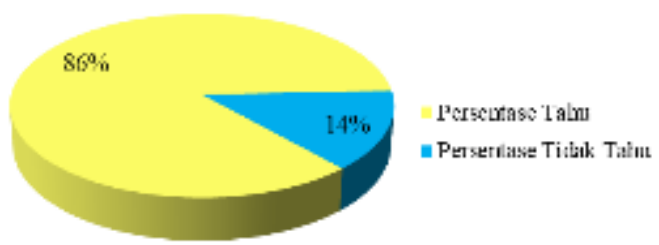

(a) Guru



(b) Peserta Didik

Gambar 6. Hasil kuisioner post-test Guru dan Peserta Didik

Berikut merupakan hasil perbandingan pre-test dan post-test guru dan peserta didik SMAN 2 Siak Hulu dapat dilihat pada Gambar 7.

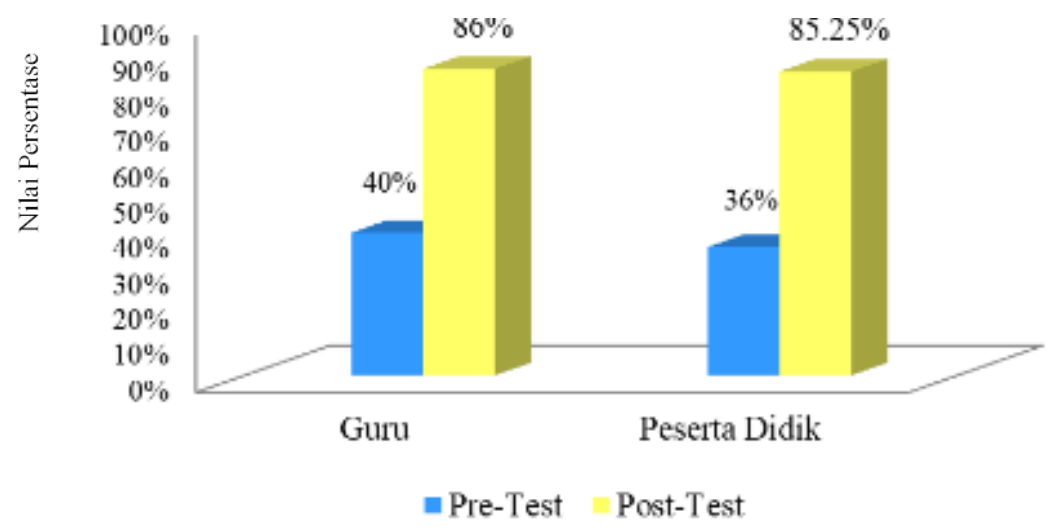

Gambar 7. Grafik Perbandingan pre-test dan post-test Guru dan Peserta Didik

\section{Evaluasi, Review, dan Follow up}

Evaluasi dan review; Guru dan peserta didik telah mengenal dan memahani manfaat Edu-PHOTSIC sebesar $86 \%$ dan $85 \%$. Hal ini membuktikan bahwa keberhasilan tim Edu-PHOTSIC dalam penyampaian kegiatan Edu-PHOTSIC mengenai penggunaan dan pengerjaan soal HOTS kepada guru dan peserta didik SMAN 2 Siak Hulu.



(a)

Antar guru membahas soal HOTS

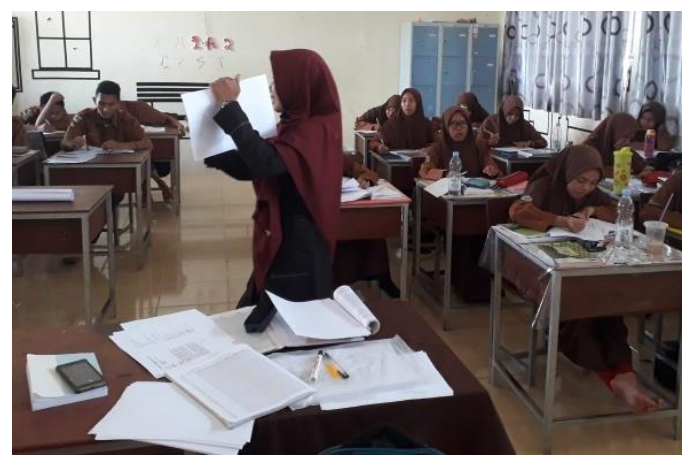

(b)

Guru mengajarkan soal HOTS ke peserta didik

Gambar 8. Hasil kuisioner post-test Guru dan Peserta Didik

Follow up; Guru dan peserta didik setuju untuk mempertahankan dan mengembangkan Edu-PHOTSIC. Beberapa kegiatan tambahan telah dilakukan guna keberlanjutan Edu-PHOTSIC, yakni penandatangan kerja 
sama antara tim Edu-PHOTSIC dengan pihak sekolah SMAN 2 Siak Hulu untuk saling bekerjasama memantau keberlangsungan program Edu-PHOTSIC dan buku keberlanjutan yang disebarluaskan kepada guru dan peserta didik untuk mengetahui seberapa jauh pelaksanaan keberlanjutan Edu-PHOTSIC yang dilaksanakan secara mandiri. Berikut kegiatan keberlanjutan yang dilakukan oleh guru dan peserta didik dapat dilihat pada Gambar 8.

Tahap Pelaporan Edu-PHOTSIC; Hasil perbandingan data dari pre-test dan post-test menunjukkan peningkatan terkait pemahaman dalam penggunaan dan pengerjaan soal HOTS, hal ini membuktikan bahwa kegiatan Edu-PHOTSIC sangat bermanfaat bagi guru kimia dan peserta didik SMAN 2 Siak Hulu.

\section{KESIMPULAN}

Berdasarkan grafik perbandingan data dari pre-test dan post-test guru dan peserta didik, maka didapat peningkatan terhadap guru terkait penggunaan soal HOTS dari $40 \%$ meningkat menjadi $86 \%$ dan peningkatan terjadi juga kepada peserta didik terkait pengerjaan soal HOTS. Hal ini membuktikan bahwa kegiatan EduPHOTSIC sangat bermanfaat bagi guru kimia dan peserta didik SMAN 2 Siak Hulu.

\section{UCAPAN TERIMA KASIH}

Ucapan terima kasih disampaikan kepada Kementerian Riset, Teknologi dan Pendidikan Tinggi atas Program Kreativitas Mahasiswa-Pengabdian kepada Masyarakat (PKM-M).

\section{DAFTAR REFERENSI}

Kemendikbud. 2017. Panduan Implementasi Kecakapan Abad 21 Kurikulum 2013 di Sekolah Menengah Atas. Jakarta: Direktorat Pembinaan SMA Ditjen Pendidikan Dasar dan Menengah.

Puspendik. 2017. Laporan Hasil Sekolah Ujian Nasional SMA/MA. Jakarta: Kemendikbud.

Dafitri H. 2017. Pemanfaatan Wondershare Quiz Creator dalam Tes Berbasis Komputer. Jurnal Sistem Informasi. Vol 1:1. Medan: ST Teknik Harapan.

Sugiyono. 2015. Metode Penelitian Pendekatan (Pendekatan kuantitatif, kualitatif, dan R\&D). Bandung: Alfabeta.

Sa'adah, I.S., A. P. Manju, Nurhasanah, R. Linda. 2019. Printed and IT THOTSIC as a Benchmark of Students's Ability in Facing the National Examination. Journal of Educational Sciences 3(1): 96-105. 